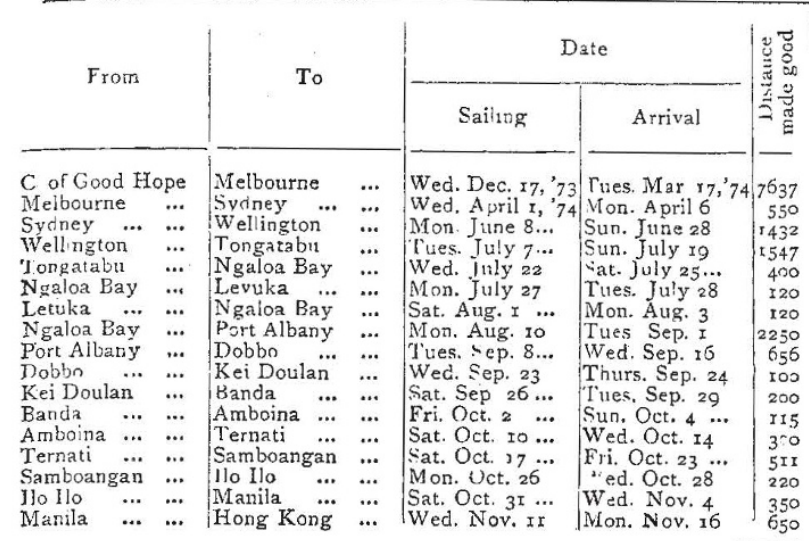

Total of Second Section of Voyage $\quad . . . \quad \ldots \overline{\text { r7158 }}$

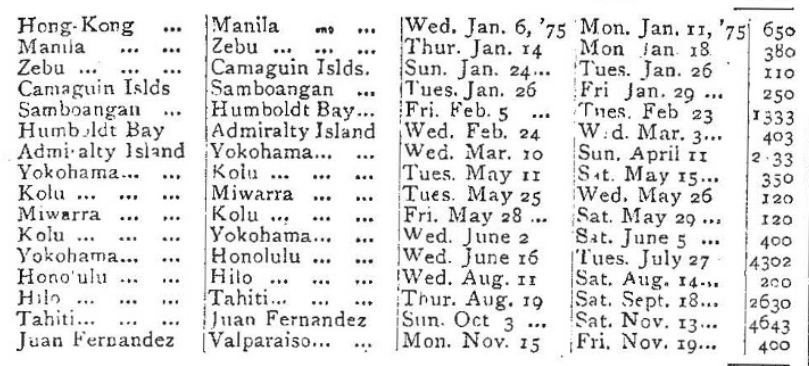

Total of Third Section of Voyage

Valparai:o ... Messier Channel Sat. Dec. II, '75 Sat. Jan, ',5 In Magellan Straits Channel Sat. Dec. 11,75 Sat. Jan, 1, 76 2033 \begin{tabular}{l|l|l|l|l|l} 
Magellan Strts... & Falkland Isids.... & Thurs. Jan. 20 & Sun. Jan. 2.3 & 710 \\
\hline
\end{tabular} Monte Video $\ldots$ Sun. Feb. 6 ... Tues. Feb. I5 II72 \begin{tabular}{ll|ll|l|l|l|l|} 
Monte Video &.. & Ascension $\ldots$ & $\ldots$ & Fri. Feb 25 & Mon. Mar. 27 & 3720 \\
Ascension ... & $\ldots$ & St. Vincent & $\ldots$ & Mon. April & $\ldots$ & Tues. April I8 & 1800
\end{tabular} \begin{tabular}{ll|ll|l|l|l|l|} 
Ascension $\ldots$ & $\ldots$ & St. Vincent & $\ldots$ & Won. April $3 \ldots$ & Tues, April I8 & 1800 \\
St. Vincent & $\ldots$ & Vign $\ldots$ & $\ldots$ & $\ldots$ & Wed. A pril 26 & Sat. May 20 & 2846
\end{tabular}

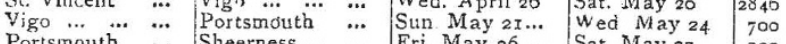
\begin{tabular}{ll|l|l|l} 
Portsmouth ... & Sheerness ... ... & Fri. May $26 . .$. & Sat. May 27
\end{tabular}

$\begin{array}{lllll}\text { Total of Fourth Section of Voyage } & \ldots & \ldots & \ldots & \text { r }_{358} \mathrm{r}\end{array}$

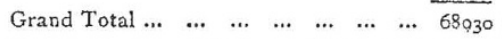

\section{NATURAL HISTORY AT THE ROYAL} $A C A D E M Y$

WE will leave to other journals the task of criticising the present Exhibition of works of Art at the Royal Academy, and without entering deeply into the question of grouping composition, solidity of painting, chiaroscuro, perspective, morbidezza of flesh treatment, or aerial effect, we will confine ourselves to a few remarks in a less ambitious key, on those pictures which portray animal life. Of this class there are several important examples devoted entirely to the representation of wild or domesticated animals, with others in which the lower forms of creation play but a slightly inferior part ; and in these days when the public taste claims a far more conscientious treatment of the subject than in former times, we may be allowed, without being taxed with unfair criticism, to examine how far the respective artists have succeeded in fidelity of execution.

In the first gallery the eye is at once attracted to a large work by Mr. F. Goodall, R.A., "An Intruder on the Bedouin's Pasture" (I4), representing a Nubian riding on a dromedary accosting some nomads. The drawing of the centre camel is excellent, although the animal is perhaps a trifle too clean and shiny ; the other camels are somewhat unequal in point of execution. In the foreground are some capitally painted goats, and a scarabeus is crawling along the sandy bank, whilst on the left by a small pool of water, two wagtails are strutting, one of which was evidently drawn from a badly stuffed specimen. The distance and atmosphere are admirably rendered, far better than in another picture where camels are also the prominent objects, that of $\mathrm{Mr}, \mathrm{R}$. Beavis, $(85)$., "Bedaween Caravan on the Road to Mount Sinai," in which the atmosphere is somewhat cold and grey. On the other hand, the action of Mr. Beavis's two advancing camels is perfect, whilst the position selected is one of extreme difficulty; there is a roughness and vigour in these animals that make $\mathrm{Mr}$. Goodall's dromedaries look by comparison like mere stuffed models. In his other contribution, "Ploughing in Lower Egypt" (484), representing a buffalo and a camel yoked together, Mr. Beavis has been less happy ; partly, perhaps, because the union of such an incongruous pair cannot look otherwise than ungainly. To the right, some way off, are several birds feeding by the side of the water, and we can just see that they are cranes of some species, which at that distance is all that could be required; but unfortunately there is another bird with these which is only too plainly recognisable, and that is the sacred ibis, which we cannot believe that Mr. Beavis or anyone else has seen in Lower Egypt in the present century, although it was apparently more widely distributed in ancient times. It is indeed doubtful if it still exists in any part of Egypt proper, and the bird usually pointed out to travellers as such by the Nile dragoman, is the buff-backed heron. Mr. J. W. Oakes, A., in his "Sheltered" $(36)$, gives some young gulls in the foreground which have at least the merit of being recognisable as young Lanus ridibunduss, but the drawing of the flying bird's wings and tail is sadly wrong. Mr. S. Carter's "Morning with the Wild Red Deer" (47), depicts a noble stag of twelve points lying down with a hind and fawn; the rough hair is capitally rendered, but we are a little doubtful as to the accuracy of representing paterfamilias in such company. Of the same artist's "A Noble Victim" (74), a stag fallen dead by the side of a pool with a colly. dog showing his teeth at a young eagle perched on a neighbouring rock, we cannot speak so highly, for the work seems somewhat thin and scamped. His No. 1257, "A Little Freehold," is a family party of squirrels, the young one issuing from a nest like that of a dipper, placed in the large fork of a tree-utterly unlike any squirrel's drail we ever saw.

The first of the works of Mr. J. E. Hodgson, A., "The Temple of Diana at Zaghouan" (84), hardy comes within our scope, but it is a charming composition, showing a sportsman, presumably the artist himself, intruding like a modern Actäeon upon a pool in which several Moorish maidens are washing; the savage glances of the black attendants and the curiosity of the girls are humorously given. The spaniel in the foreground must be our excuse for noticing this picture at all, and we are sorry to say that the $\operatorname{dog}$ is the worst figure there ; but 30I, "Following the Plough," comes within our lawful bounds, depicting as it does, a Moor ploughing, followed by several storks which are gathering worms and grubs from the newly turned furrows, whilst on the bushes to the right are perched a hoopoe and a goldfinch. None of these birds are really faultless, but a very conscientious effort has evidently been made to reproduce on canvas the grotesque actions of the storks, and we have no doubt that the artist could easily improve upon this first ess $t y$ in bird-life.

Of Mr. Millais' grand work, "Over the Hills and Far Away," (I06), we need only remark the fidelity of the representation of the hovering kestrel to the left, and the distant pacl: of red grouse in the distance on the right. the old cock grouse stands crowing on the top of a rock. It has been stated that these birds are meant for blackgame, but those who say so had better look again, ard they will recognise the touch by which the master-hand has indicated the species. Mr. Hook's first work in the catalogue is No. 44, "Sea-side Ducks," in which the ducks are by no means equal to the fish, cod, skate, whiting-pont, 
and gurnard, which lie in well-arranged confusion at a little distance, whilst in No. 186, a carefully-painted dogfish and skate are seen lying on some crab pots. In No. 234 , "Crabbers," there is abundance of motion in the boat which is just taking in a wave over the bows as one of the fishermen hauls in the crab-pot, but what shall we say of the fine male crab which he is extracting? The face of the crustacean is towards the spectator, but will it be believed that an artist of Mr. Hook's experience has actually placed the huge claws behind the legs, instead if in the front! Think of the outcry there would have been, if in that over-discussed horse in the "Roll-call," about whose action nobody could agree, the artist had chosen to put the fore-legs where the hind-limbs should have been: it would have been treated as an insult to common sense, for every one knows, or thinks he knows, the points of a horse. But a mere crab, poor cancer pagurus, what does it matter where his nippers are placed? We sincerely hope that when Mr. Hook has orcasion to paint a live lobster he will not paint it red, although this would be by far the more trivial error of the two.

It is needless to say anything of Mr. T. S. Cooper's cattle pictures, for we have seen the same kind of thing as long as we can remember. In 243, "An Inquisitive Magpie," Mr. Jones has some brown sheep in a brown atmosphere, contemplating a stuffed magpie on a hurdle ; the picture is hopelessly "skied," but it may be satisfactory to the artist and to Mr. Y. V. Duffy, whose excellent "Flood in the Dargle" hangs next at a similar elevation, to know that their works help materially to tone down the too advaricing brown of the tree trunks in Mr. Leighton's "D aphnephoria," hung immediately below.

"Early Summer" (168), by Mr. H. W. B. Davis, A., is a clever landscape with Devon cattle; but by far tha grandest work which has ever proceeded from his brush is " Mares and Foals, Picardy " (557), a picture which may challenge comparison with any similar subject by Landseer. In the foreground a foal, bitten by a fly plainly visible on its neck, is plunging wildly over another foal which is lying down; the centre figure is a large white mare, whinnying and showing her teeth at another member of a group which seems generally out of temper, whilst the mare and foal to the left, in repose, are simply perfection. The great mass of white in the centre is most difficult to manage, and in certain lights there is something not altogether satisfactory about the shoulder on the off-side, but when the direct glare of the sun does not fall on the picture, this apparent defect disappears.

Mr. B. Riviere has not been fortunate with his Ducks in a "Stern Chase" ( 353$)$, and the art critics do not seem favourably disposed to his (496), "Pallas Athene and the Herdsman's Dogs; " but putting the figure of the goddess out of the question, the dogs, which are uncommonly like wclves, are really well drawn, and the attitude of the one rolling on its back is excellently given. There is much humour in the expression of the big mastiff looking down on the skye terrier in Mr. O. Weber's "How do you do" (4I6), and as they are stated to be portraits, we cannot quarrel with the head of the former, but his chance of a prize at a dog show would be small. In "Home Ties " (435), Mr. E. Douglas gives us a foxhound and litter in kennel, and in 556, "A Bagged Fox," a capital fox-terrier, standing on and watching intently the movements in a sack, from which the bagged fox is just gnawing his way out ; in the foreground are two red herrings tied to a cord, indicating that the hounds are generally hunted on the drag, and that a fox is an unwonted luxury-probably he bas been purchased 10 give a brilliant wind up to the season. Two other sporing pictures $23 \mathrm{~F}$, by W. $\mathrm{H}$. Hopkins, and 357 by S. Pearce, are commendable.

Mr. Ansdell has abandoned Spain this year, and all his pictures but one represent Scotch scenes. In 214 we have the well known black and white ponies, whilst 619 represents some half-drowned sheep recovered by the shepherds; the fore-legs of the sheep standing upright are absurdly small and out of all proportion. The colly. dog which has just killed a hill-fox caught in the act of devouring a lamb (874), is painted in that artist's usual style, for in dogs he has now no rival, but we miss the life and expression which Landseer used to give to his canine friends. Mr. P. Graham's "Moorland Rovers" (385), a couple of shaggy Scotch cattle, would look better if they were painted on a smaller scale, and the green of the reeds in the foreground strikes us as somewhat vivid in colour.

Mr. Heywood Hardy's 899 is a somewhat ambitious attempt to represent an extremely difficult subject-the animals coming to Noah's ark. It would appear that the artist started with the intention of confining his choice to members of the African or Ethiopian fauna; there are ostriches, giraffes, African elephants and buffaloes, sable antelopes, Dorcas gazelles, and other species, wbilst the most obtrusive figures are those of two hippoporami, one of which is opening its enormous jaws to their fullest extent. The deep red of the interior of the beast's muth bas unfortunately necessirated a very serious departire from the original plan, and led to the introduction on the right of the picture of two scarlet American ibises, whose office is clearly to tone down the red of behemoth's mouth. We are not altogether satisfied with the presence of the Syrian bear, the horse, and the wild ass, in such company. The foreshortening of the pelican's wing on the left is also incorrect, and, indeed, the birds in general are not satisfactory; but we have to thank Mr. Hardy for clearing up a point which has hitherto been unexplained. We never could understand why the raven never returned to the ark; but after viewing the bird which is looking up wistfully at Noah's feet, and evidently wondering how he is to get up there without anything to walk upon, we see the reason only tos plainly. From the moment that Noah inhumanly "sent him forth," his minutes were numbered; a couple of despairing flops of his incapable wing;, and unless Noah promptly lowered a boat, the corpse of the corpse-devourer must speedily have become the sport of the waves which then united the Black and Caspian Seas. But with all its defects, Mr. Hardy's picture is a most meritorious altempt at portraying animals as they really are; nearly every species has evidently been drawn from the live specinens in the Zoological Gardens, and we sincerely trust that the artist will persevere in the line which he has selected.

Miss A. Havers has been very fortunate in her delineation of geese in "Gonsey, Goosey-gander" (1266): a girl sitting on a foot-bridge at evening, watching a flock of geese wading in the burn; one of the flock is leaving the rest, and waddling off to the wrong side of the water. It is not everyone who can paint a goose, and it would be difficult to imagine a more accurate representation of the ungainly motions of that despiser bird. Equally good in its way is the rendering of the action of a mule just at starting, in Mr. W. J. Hennessy's "En fête, Normandy" (523), which is moreover a charming composition.

It is sad to have to no:ice such painful failures in animal painting as those of Mr. C. Landseer, R. A, "A Watch Dog" (420), and Sir F. Grant's "The Muckle Hart" (I $34 \mathrm{I}$ ); in the latter the recumbent stag has hardly one of his tynes correctly drawn, and the hind in the distance is a fearful and wonderful beast.

With regard to the Statuary, it is difficult to find a place in the lecture-room, whence a good view can be ob'ained of J. E. Boehm's enormous equestrian group of St. George and the Dragon; but the dragon deserves notice as being a compound of several existing reptilian forms; thus approaching reality as far as is possible with a semimythical monster. The body of the dragon is that of a crocodile, the neck and head are those of the Cerastes or horned viper, whilst the wings are modelled after those 
of the small flying lizard. Mr. G. A. Carter's "Grolip of Red-deer" (I 405$)$ is not a great success, but it will probably look better when executed in silver. There is much merit in Mr. W. Prehn's "Polar Bears" (1455), in which the artist has coloured the snouts and slightly washed the limbs of the animals with yellow to relieve the deadness of such a mass of wbite; an excusable innovation in the present instance. And last in order we come to two admirable models of "A Wild Boar" (I5OI), and "A Bear" (1507), by Mr. Joseph Wo'f, whose repulation as a delineator of animal life with the brush is unrivalled, but who has never till now turned his attention to modelling The attitude of the boar is excellent : his face is devoid of any expression, although he has evidently partaken of some vegetables whose remains lic at his feet, but withal the, $e$ is no sign of $\in$ njoyment or satisfaction. It is otherwise with the bear, who has been devouring honey-comb, and who is now licking his chops with an expression worthy of a gourmand, showing that the good things of this life are by no means wasted upon a gentleman of his appreciation. And with this we close our notice of animal life at the Academy, congratulating artists in general upon the increasing tendency to paint their subjects from nature instead of evolving them out of their own inner consciousness.

TwO NATURALISTS

\section{THE ETHNOLOGY OF THE PAPUANS OF MACLAY COAST, NEW GUINEA}

I December 1873, when at Batavia, I received from 1 the Russian travcller, Von Miklucho-Maclay, reprints of two articles upon the East Coast of New Guinea and its inhabitints, of which I made a short abstract for NATURE (Feb, 26, I874), during my voyage from Jara to Atchin. The following is the substance of one of two supplementary papers on the same subject, ${ }^{1}$ which have been lately sent to me, by Dr. Maclay, from Johore, on the Maldy peninsula; which, it would be imagined, should be all the more interesting, as much which is, to say the l ast, doubtful, has lately been published about $\mathrm{New}$ Guinea and its natural productions.

The former papers dealt with the individual characters of the Pafuans, while in the present article the food, weapons, dress, dwellings, and daily live of this people will be treated of.

The Food of the Papuan. - That of the inbabitants of Maclay Coast is principally of a non-animal nature, consisting of fruits and vegetables, of which a list is subjoined in the order of their domestic importance.

The Cocoa-nut (munki). This plays a most important part in the economy, as it is obtainable all the year round. The trees are seldom to be met with in the mountain villages, but are numerous on the shores of the neighbouring islands, though here they are confined to plantat:ons around the houses. A favourite dish which never fails at feasts is munki.la, a kind of porridge made of the grated kernel of the nut steeped in the so.called "milk." Curiously enough, the preparation of cocoa-nut oil is unknown.

The Dioscorea (ajan) is much cultivated in the plantations, and is in condition for lood from August till January. It is boiled in water, or when this is difficult of carriage, roasted in ashes. In forms the principal article of dit during the above-ramed months.

The Collucas a (bau) is the main article of food from March to Augus:. Like the ajan, it is either boiled or baked. Pounded up with grated roasted cocoa-nut, it is made into a kind of cake, which is in great request at feasts. The leaves of the plant are also eaten.

The fruit of the Convolvulus (degargol), of which there are two varieties, one red, the other white, is principally

I "Ethnolcgische Bemerkungen über die Papuas der Maclay.küste in Neu Gunea." Reprinted from the Natuurkundis Tija:chrift of Batavia. in season in September and October, and is either stewed or baked.

Although no less than eight or nine varieties of Banana (moga) were met with by Miklucho-Maclay, owing to its limited cultivation, the fruit is a comparative rarity. The lower part of the stem and the roots of the young plants are also eaten.

On account of the rare occurrence of the Palm affording it, sago (buam) is rather a dainty, seen only at feasts, than an article of daily diet.

The Sugar-cane (den), which attains a magnificent growth in New Guinea - the edible portion being not infrequently fourteen feet high-is chewed with the greatest zest by men, women, and children, from October to February.

The Bread-fruit (boli), though not particularly sought after, is collected and eaten stewed or roasted.

The Orlan is the fruit of a tree which Dr. Maclay had no opportunity of seing. This fruit is hung in great baskets upon the trees in the forests. From the pulp and the kernel of the crushed seed there is derived by fermentation an acid unpleasantly smelling sauce, which is considered a great delicacy.

The Canarium commune (kengar) is collected in May, June, and July, dried, and its seed stored.

The fruit of the Prndanus (Screw Pine) and Mangifera (mango) also occurs, but very sparingly, on Maclay Cozst. Animal food is of but rare occurrence. The following animals are, however, the most usual sources of food :-

The Pig.- This, a descendant from the wild New Guinea species, is bred in the villages. When young it is striped, but with age it becomes black. The ears are erect, the snout sharp, and the legs long. Pigs are only killed on festal occasions, and then one suffices tor two or three villages.

Dogs are kept by the Papuans principally for the sake of their fesh, which, though of fairly good flavour, is, nevertheless, somewhat dry.

The flesh of the Cuscus ${ }^{1}(m a b)$ is considered a great dainty, although it has a strony smell.

Fowls, although they occur in the villages, are but seldom eaten ; and, as they exist in a semi-wild state, their eggs are not of ten to be obtained. During a stay of fifteen months Dr. Maclay only saw two egys in the various villages which he visited.

From the large lizards (Monitors) a white and tender meat is obtainable.

All insects without exception, especially large beetles, are eaten, either raw or cooked, by the Papuans.

As regards fishes, the larger are caught in nets, while the smaller are killed by harpoon at night time.

Various molluscs and other shell fish are collected on the coral reefs at low water by the women and children of the villages.

As the existence of salt is unknown here, the Papuans cook their food with a little sea-water-uenerally onethird to two-thirds fresh water-and the inhabitants of the hills never omit to take away with them a bamboo filled with sea-water when they visit the coast. The Papuans have, nevertheless, a substitute for salt, for they collect the tree-trunks which, after soaking for a while in the sea, are cast up at high tides, dry and burn them, and thus procure therefrom a saitish tasting ash.

The manufacture of intoxicating drinks is, moreover, not unknown among the Papuans. They take the stem, leaves, and especially the root, of a certain shrub called "keu" (Piper methisticum?)! this they chew, and the resulting mass, when sufficiently masticated, is spat out with as much spittle as possible into a cocoa-nut shell. A little water is added to this, and, after the dirty greenlooking brew has been filtered through some grass, the tillrate, which is very bitter and aromatic, is drunk off. 'This liquor does not taste particularly good, as is proved by 